\title{
MANO A MANO: HERMES Y EL SPOUDOGÉLOION Vigencia e importancia de los géneros clásicos en la teoría bajtiniana de la novela
}

\author{
Estébana Matarrita Matarrita
}

\begin{abstract}
RESUMEN
Este artículo es un análisis de los elementos cómico-genéricos que muestra una novela costarricense y que pertenecen a la tradición clásica con la que Bajtín asocia el origen genuino de la novela contemporánea.
\end{abstract}

\begin{abstract}
This article presents an analysis of the comic and generic elements in a Costa Rican novel. These elements are part of the classical traditin Bachtin associates with the genuine origin of the contemporary novel.
\end{abstract}

Virgilio A. Mora es uno de los escritores contemporáneos de la literatura costarricene Se dio a conocer en 1979 con una novela titulada Cachaza, la cual, si bien supo cautivar el interés de un público bastante amplio, su aparición no dejó de crear un tipo de polémica. Las incomodidades que esta obra ocasionó se debían, además del por sí álgido tema de la locura que estaba en su centro, a un cierto juego textual con las referencias que parecían hacer alusión a la realidad inmediata. En ella se movían ciertos personajes de la vida nacional y se le hacía - crítica a un gremio: el de los médicos; y a la práctica de una profesión: la psiquiatría.

A pesar de ello, a estas alturas, Cachaza se ha ganado un puesto en la historiografía lierria nacional, ya que fue incluida entre las veinticinco obras más representativas de la literaura costarricense. Estas obras se publicaron en una colección especial, elaborada por la Edito- -ill Costa Rica con motivo de la celebración de su vigésimo quinto aniversario. Además, esta mwela es parte del programa de los cursos de literatura costarricense en la Escuela de Filolo27. Linguística y Literatura de la Universidad de Costa Rica. Sobre Mora se han presentado en = misma casa de estudios algunas tesis de grado y en esta revista se han publicado varios ar-uilas sobre sus relatos. Ni qué decir de los estudios que le ha dedicado María Amoretti, entre tiliss un libro y otro más que tiene en preparación, según nos ha contado. También es de notar Z es uno de los pocos autores contemporáneos de la literatura costarricense a quien se le ha - inicado un seminario en el Plan de Estudios de Filología Española, en esta misma universi- irmpartido también por la profesora Amoretti. Amoretti es quizá la mejor conocedora de su Zn y es gracias a ella que la autora de este artículo ha seguido la misma afición. 
Sin embargo, actualmente las obras de Mora comienzan a trascender los límites del territorio nacional, pues últimamente, en España, la crítica literaria Margarita Borreguero ha escrito algunos comentarios y reseñas y es ella justamente quien realiza el excelente estudio crítico de la edición de este libro utilizada para la elaboración de nuestro artículo.

En términos generales, es mi opinión que el éxito de la obra de Mora se debe a dos motivos: el primero es el nivel técnico alcanzado en el arte narrativo; el segundo, que se logra gracias al anterior, es su proyección crítico-ideológica, cuya eficacia se asienta en el uso de los géneros burlescos que Bajtín destaca, recurriendo a la tradición clásica de los spoudogéloion como trascendentales en el desarrollo histórico de la novela.

Apoyada en esta tradición clásica, a la que me he dedicado por muchos años, voy a intentar un enfoque que penetre las capas filosóficas que su arte narrativo implica y los efec-

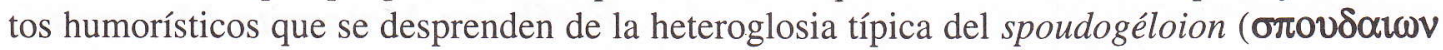
= tratar con seriedad, con cuidado. yeגotov = lo risible, lo gracioso. Tratar con seriedad algo gracioso, risible). Actualmente, Mora es uno de los escritores más prolíficos del país, pero la simpatía por su obra continúa siendo discutible. Quizá, quien mejor ha descrito esta situación sea María Amoretti (1995:8) en un artículo suyo titulado "El odioso de Mora", en el que dice:

Hablar de Mora o de su obra siempre es riesgoso. Hombre y obra, la misma cosa, controversiales. No se puede hablar de ninguno de los dos con impunidad. Siempre se corre el riesgo de una de dos alternativas: la aprobación entusiasta o el gesto de repugnancia. A Mora se le quiere o se le aborrece. No hay términos medios. A su obra se le admira o se le tira al basurero. Con cualquiera de los dos, el hombre o la obra, no hay posible indiferencia.

Mora nace en un barrio del sur de San José, capital de Costa Rica. Decir barrio del sur significa suburbio marginal en el ideolecto capitalino. No en vano, el nombre de ese barrio es Desamparados. capital.

Realiza sus estudios primarios allí y termina la secundaria en un colegio público de la

Con una pequeña beca, y al amparo de alguno de sus familiares exiliados en México después de la Revolución de 1948 en Costa Rica, se marcha muy joven a la capital azteca para seguir estudios de medicina. Con sus 19 años y el ímpetu propio de la juventud, la brillante capital mexicana de los años 50 lo cautiva y, entre los estudios y las borracheras, el joven lleva una vida pícara, destinada a gozar y descubrir todo lo que esta le ofrece.

Regresa a San José, pero pronto se da cuenta de que necesita horizontes más amplios que el contexto todavía aldeano de aquella ciudad y se marcha a Estados Unidos, donde realiza dos especialidades: psiquiatría y neurología.

Desde entonces vive allí. De eso hace más de 35 años.

El tema de sus obras es ese: su vida, lo vivido, y su interlocutor es, a todas luces, la comunidad costarricense.

Se ha afirmado mucho, entre otras cosas, el carácter innovador de los escritos de Mora, pero quizá en ninguna obra suya se acentúa más la vocación experimental de este escritor como en la novela objeto de este artículo, Mano a mano.

En este relato, cuyo intertexto obvio es Niebla de Miguel de Unamuno, personaje y autor se enfrentan. Según la historia, que se nos ofrece dentro de un juego de voces narradoras bastante difícil al inicio, Mora había terminado en Bordeaux su novela Memorias de un 
psiquiatra, la historia de Polo Moro, durante unas vacaciones en Europa. Esto acaece el 29 de noviembre de 1990.

Cuatro años más tarde, realiza un nuevo viaje a Europa para celebrar sus 60 años. Mora regresa entonces a esa misma ciudad y allí su famoso personaje Moro cobra vida, por segunda vez y de una manera distinta, en su propio lugar de nacimiento. Inexplicablemente, el ente de ficción aprende el funcionamiento de la computadora que lo contiene y desde ahí interfiere la correspondencia que sostiene el autor con su amiga, una crítica literaria de apellido MacDowell de Saint Ken, a quien debe advertirle de la situación, pues además Moro ha comenzado a escribirle a ella imitando el estilo de Mora y suplantándolo. Esta suplantación le resulta fácil a Polo Moro, ya que él no es otra cosa que el sujeto de la pseudoautobiografía (el doble) que Mora había inventado en su novela Memorias de un Psiquiatra, como ya lo hemos mencionado. Cito:

Gerty MacDowell:

No sólo a ti. También le ha escrito a varia gente que conozco. Pero eso no es todo: también empezó a escribir una novela usando mi nombre... mi nombre, Gerty. He creado un monstruo (Mora 1998: 31).

Para los lectores que conocen la obra anterior, no es difícil comprender este fenómeno y las razones de su aparición, pues en la citada pseudoautobiografía se había iniciado lo que Bajtín llama una exotopía, una salida de sí.

Según el filósofo ruso, este fenómeno tiene dos etapas: primero, el novelista crea un personaje materialmente distinto de sí mismo con el que establece una situación de empatía, pues el novelista se pone en el lugar de su personaje (En Todorov 1981). Luego se da un movimiento inverso por medio del cual el novelista se reintegra a su propia posición. A este segundo aspecto de la actividad creadora se le llama exotopía (que en realidad es un término dado por Todorov como equivalente al término ruso empleado por Bajtín). Exotopía significa "encontrarse afuera". Ambos movimientos son necesarios porque solo fuera del personaje podrá el autor completarlo, darle forma. Pues bien, en Memorias de un Psiquiatra, el autor es esa conciencia que hace del personaje un todo completo, es quien provee los elementos indispensables para esta completud.

No obstante, según Bajtín, la mejor exotopía será aquella que no encierre al personaje dentro de la conciencia del autor. En Memorias de un Psiquiatra, el personaje todavía no tiene voz en ese diálogo que el autor establece con él. En cambio, en Mano a Mano acontece finalmente la réplica, a pesar del autor, quien sabe, mejor que nadie, que Polo Moro no es nada fiable.

Así, si en Memorias de un Psiquiatra el autor completaba la imagen del personaje, en Mano a Mano es el personaje quien completa la imagen del autor.

Este cambio de relación entre autor y personaje es lo que inaugura Dostoievsky en la historia de la novela como género; pero será Miguel de Unamuno quien hará de esa relación el tema de su novela Niebla, y Mora quien la lleve a su máxima intensificación en Mano a mano, pues allí el personaje efectivamente salta de la página electrónica para entrar en esa otra realidad en la que el autor dice estar.

La picardía de Moro va a provocar, no obstante, mucho humor en este texto. Veamos el primer encuentro cara a cara entre los dos: 


\begin{abstract}
Llegué picado.
Empero, apenas lo vi, se me bajó el coraje, las ínfulas. Parecía invisible para el resto de los parroquianos, para el dueño del lugar y completamente ajeno a su indumentaria ridícula... me dio pena el hombre, lo saludé, nos saludamos, me invitó a una cerveza tal como yo lo había programado, me tomé en vez de la cerveza un tinto, bebimos con ganas, hablamos, y al final me convenció de que lo que me molestaba de su realidad era sólo su autonomía, con qué derecho, me preguntó, usted se cree Dios, todos somos criaturas del señor... Permítame disfrutar de su realidad a la que he llegado a través de la palabra, déjeme existir, probar un mundo que no es muy diferente al mío pero que ofrece más, que es más proteiforme, más lleno de sorpresas, más irreal que el mío aunque le parezca mentira (Mora 1998: 33).
\end{abstract}

Si la historia nos recuerda mucho la problemática de Niebla de Miguel de Unamuno, las diferencias son, al mismo tiempo, tajantes. Una de ellas es el tono elegido por Mora, tono que Bajtín señala como típico del spoudogéloion. Al respecto, afirma el filósofo ruso lo siguiente:

\begin{abstract}
De este medio de la risa popular en el terreno antiguo crece directamente una esfera bastante vasta y variada de la literatura antigua que los propios antiguos llamaron expresivamente spoudogeloion o sea, la esfera de "lo serio-cómico". Aquí se incluyen las pantomimas poco argumentales de Sofrón, toda la poesía bucólica, la fábula, la primitiva literatura de memorias

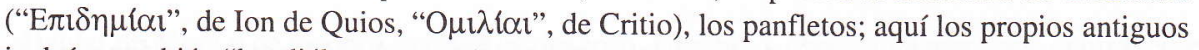
incluían también "los diálogos socráticos" (como género); aquí se incluye además la sátira romana (Lucilio, Horacio, Persio, Juvenal), la amplísima literatura de los "simposion" y, por último se incluyen la sátira menipea (como género) y los diálogos al estilo de Luciano. Todos estos géneros abarcados con el concepto de "lo serio-cómico", constituyen verdaderos antecedentes de la novela" (1989: 534-5).
\end{abstract}

La cita anterior demuestra el extremado conocimiento que Bajtín tenía de la cultura clásica, lo cual no debe sorprender si recordamos que el primer grado que obtuvo fue en Estudios Clásicos (1913-1918). Esta sólida preparación en ese campo específico explica el escogimiento de muchos de los tópicos y de las muestras elegidas por Bajtín en sus libros. Ello también explica el enorme atractivo que este téorico ha generado últimamente en nuestro departamento de Filología Clásica de la Universidad de Costa Rica, lo cual también ha producido un enriquecedor acercamiento con los colegas de Filología Española, pues ahora compartimos referencias teóricas comunes en el análisis textual.

Sin embargo, volviendo a la referencia que hacíamos de la novela de Unamuno, vale la pena interrogarse también sobre el porqué de estas coincidencias con la novela de Mora. $\mathrm{Pa}$ ra ello es menester considerar el significado del escritor español en el desarrollo de la novela moderna, muy especialmente en lo que concierne a sus elaboraciones metaficcionales. Niebla es, efectivamente, uno de los primeros relatos hispánicos (si no el primero), en problematizarse a sí mismo, cuestionando la naturaleza misma de la ficción. Pero, si bien Mano a mano sigue a Unamuno en ese afán, otra es la intensificación del experimento de Virgilio A. Mora, ya que su personaje, Moro, no se deja victimizar como Augusto Pérez y no sólo logra trasladarse de un archivo a otro de la computadora, sino que escapa finalmente de los límites del libro, como ya se verá.

Pero hay más. Polo Moro publica en una segunda edición, con su nombre, una novela que Mora había publicado bajo el sello de la Editorial de la Universidad de Costa Rica. La prueba está en el catálogo de Ediciones Universal, en la Florida, Estados Unidos, en el que inverosímilmente su libro, La Película, aparece bajo el nombre del propio personaje: Polo Moro. ${ }^{1}$ 
Por otra parte, la diferencia más evidente entre Niebla y Mano a Mano es la situación sociolingüística, la cual es mucho más complicada en el relato de Mora al incluir también niveles diversos en el plano del interlocutor, al mezclar el género epistolar con el narrativo y el dramático, al confundir planos diegéticos y temporales y voces de variadas procedencias y estratos, amén de las posibilidades que le dan los nuevos medios electrónicos.

Frente a la seriedad filosófica de la novela de Unamuno, la de Mora es una versión carnavalizada de ésta, en la que el autor será quien lleve la peor parte.

Pero, además del intertexto de Niebla, aparece otro intertexto muy obvio: "Las ruinas circulares" de Borges, otro escritor de relatos experimentales que produce no sólo metaficciones, sino también hipertextualizaciones capaces de elevar la semiosis del texto a niveles de elucubraciones filosóficas sumamente sofisticadas. Mora intenta lo mismo pero por otros medios, muy lejanos de las elevadas disquisiciones discursivas de estos autores. Pronto veremos por qué. Mientras tanto, volvamos al hilo argumental de Mano a mano.

Después de que el autor le niega ad portas su libertad, Polo Moro comienza una serie de estratagemas para disuadirlo. El personaje está dispuesto a conseguir su libertad a toda costa, sin importar los medios. Para lograrlo, decide sabotear todo lo que el autor ha escrito y tiene guardado en su computadora.

Un día inventa una fiesta con todos los personajes de los diferentes textos guardados por Mora en su ordenador. Aquí la intertextualidad son todos los relatos anteriores del autor. Lo que sucede es lo siguiente: el autor, sospechando lo peor, se introduce en el relato de Polo. Lo sigue por unas calles de Biarritz y de repente reconoce la casa en la que se introduce Polo como la casa de una de sus novelas y entra:

\begin{abstract}
Me metí en el relato de Polo. Era una noche oscura a pesar de las luces de la ciudad, una luna llena y un cielo bordado de estrellas como el del trópico en marzo. Aunque apenas eran las ocho de la noche, no se veía un alma en las calles. Pasé por debajo de la luz del poste de la esquina. Seguí a Polo a una distancia prudente por unas diez cuadras al final de las que el trazado, la arquitectura, todo cambió, y él desapareció en una casa que no me costó reconocer aunque tenía un número, el 313, que no correspondía a esta construcción que ahora y en Francia tenía enfrente: la casa de María y de Luisita, una casa que podría adivinar en cualquier parte con sólo mirar la zona redonda, lisa, brillante como si fuera mármol, sobre la que María hacía noche tras noche y hasta la madrugada, su trabajo de lavar y planchar ropa. Entré al recinto sin titubear, y con una sorpresa que no correspondía al pandemónium febril que contemplaron mis ojos una vez que estuve adentro del 313. Ahí estaban, en esa dirección de pesadilla, casi todos mis pacientes travestis, una transexual, algunos amigos, algunas gentes fallecidas... (Mora 1998: 37-8).
\end{abstract}

Polo continúa comunicándose con María Gerty a quien confiesa todo su rencor por el "sátrapa", su "maldición china", "la sombra negra de su existencia", como ahora llama al autor. He aquí sus confidencias con la crítica literaria:

Gerty MacDowell de Saint Ken:

Morarodríguez se enteró de que te escribía. ¿Y qué? ¿no tengo derecho de cultivar amistades como cualquier otro personaje? ¿O es que tengo que depender de él para todo? Desde que tengo uso de razón, jamás me he expulsado un flato ni he defecado ni una sola vez porque al tipo le da pena enseñarme al mundo como soy. Desde que nací no he meado. ¿soy un fenómeno? Por supuesto que no. Soy el producto de un ser enajenado que me ha encadenado a una sarta de deformes y enfermos mentales en una computadora con la que se dedica a viajar inventando 
historias, mentiras, fábulas... Un Hitler el tal Morarodríguez, un tipo que ha creado un ejército de seres desaliñados, caquécticos, pálidos (como que jamás ven el sol), que jamás se bañan, que jamás defecan, pero que huelen a mierda de perro. Como que se están descomponiendo en vida, envueltos en la oscuridad y en la inactividad del abismo de una máquina infernal en donde no sale el sol, la luna, las estrellas y mucho menos un rayo de libertad. Porque el tipo se cree un Dios, nos trata como si no existiéramos. Yo, como ya de seguro te contó, me escapo de vez en cuando, y poco a poco aprendo a vivir en tu mundo, un mundo que sería mejor sin él (especialmente para mí) (Mora 1998: 45-6).

La situación llega al clímax cuando Moro por fin se las arregla para impedir que Mora lo siga. Comienza por no dejar huellas en la computadora destruyendo todo lo que escribe inmediatamente. Una madrugada, Mora se lo encuentra afuera de la máquina. Polo viene llegando de una noche de farra en compañía de Juana, una de las pacientes del Hospital Psiquiátrico de la novela Cachaza. Se trata de uno de los personajes femeninos más procaces y escandalosos. Llegan muy borrachos y, después de la sorpresa inicial de Juana -que conoce por primera vez a su autor, a quien trata de viejo y feo-, Mora le llama la atención a Polo, quien había llevado a Juana a un bar en Cuchilleros, Madrid. La escena es la siguiente:

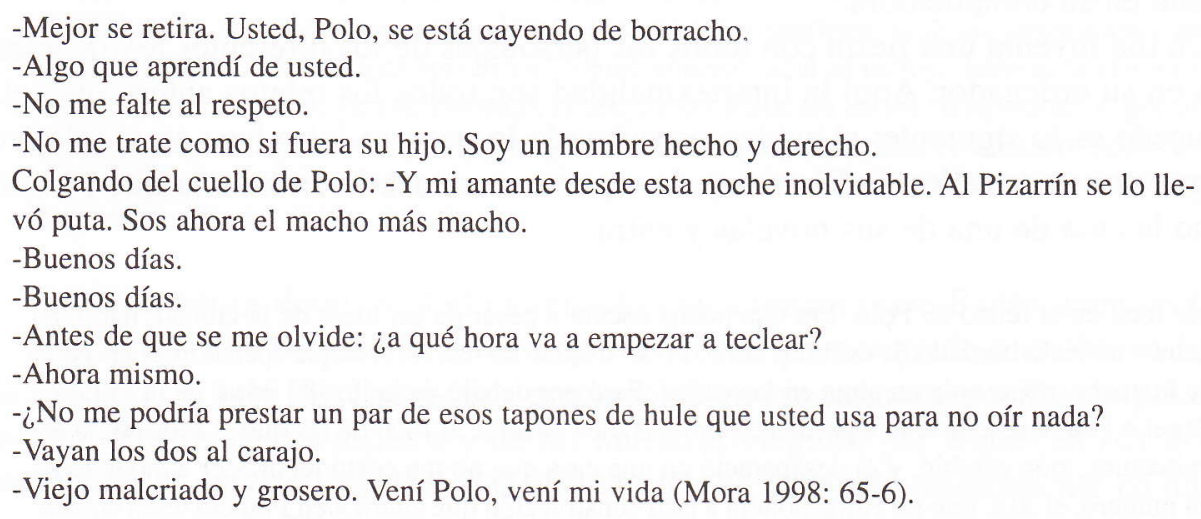

La autoridad del autor ha sido hasta este punto más que socavada; pero la guerra y el "shock" inicial entre autor y personaje se va aminorando poco a poco. Mora termina por pactar con su personaje y aceptar que Polo cumpla con su proyecto: escribir una novela y convertirse en escritor.

Polo somete, además, su texto a la consideración de la crítica, ahora amiga de ambos:

\begin{abstract}
¿Qué te parece mi enfoque, mi técnica? ¿Te interesa el relato, su complicada diégesis? En cuanto llegue a la patria grande yo, Polo, empezaré a enviarte material personalmente. Si ya tienes secciones de mi trabajo, recuerda que es muy probable que hayan sido alteradas.

Bueno, es todo por el momento, mon cheri. Se hace tarde y tengo un compromiso. No quiero correr el riesgo de que el Morarodríguez cierre esta computadora, en cuyo caso una persona que tú conoces me mataría (Mora 1998: 63).
\end{abstract}

Finalmente, Mora le servirá de asesor a Polo, quien terminará a su vez asediado también por la libertad de sus propios entes de ficción, porque la historia que escribe Polo plantea también un problema de identidad. Entre ambos, autor y personaje, se discute el destino de 
los personajes de ese relato inserto que se va construyendo simultáneamente con este otro del que venimos hablando. Pero luego el círculo de discusión se ensancha porque los personajes del personaje deciden que tienen "vela en el asınto" y de esta manera se entremezclan relatos, instancias narrativas, discusiones críticas, historias y demás elementos en un relato que, borrando todas sus fronteras, pone en evidencia lo fantasmagórico de toda narrativa, sea esta textual o social. Y lo que es más -y esto que quede al margen-, según nos cuenta María Amoretti, el proceso de producción se dio a través de una correspondencia real que ella fue recibiendo y que también la sumió inicialmente en un mar de confusiones, pues al principio no había caído en la cuenta de que efectivamente era Polo el que le escribía en ciertas ocasiones. Por supuesto que el primero en darse cuenta de que algo raro sucedía es Morarodríguez, quien así se lo comunica a la señora MacDowell:
Ahora entiendo la profusión de tus faxes ante lo exiguo de los míos; tu contestación a pregun- tas que no recordaba haber formulado, etc, etc. Ahora...ahora, como un explorador del más allá, voy camino a un encuentro con un "fantasma" por una de las carreteras que une a Tours con Bordeaux, en la "carabela" al mando de mi hijo y Golda, ignorantes ambos del sendero fantas- magórico por el que yo empecé a transitar desde ayer... (Mora 1998: 32).

Al final, Amoretti decidió seguir el juego, cuando por fin Polo se le presentó como uno de sus destinatarios y entre él y su autor decidieron ayudarla poniéndose de acuerdo los dos en escribirle uno ciertos días de la semana y el otro, en otros. Así pudo María Amoretti comenzar a entender mejor lo que sucedía y participar en el juego.

De la misma forma que se creó en varias dimensiones de la realidad, el resultado es un texto que tenemos que leer a la vez en varios planos sin transición alguna; y en el que en medio de los faxes que ambos le envían a la crítica, se intercalan los diálogos entre Mora y Moro, los diálogos de Moro y la crítica, los de Mora y la crítica, los de los tres juntos y luego hasta los diálogos entre los personajes de la novela en construcción, que unas veces discuten con uno y otras con otro, y en otras ocasiones con los dos juntos, rebelándose tanto a la versión que propone Mora como a la versión que propone Moro.

El texto francamente da vértigo no sólo por lo anteriormente expuesto, sino también por la forma en que todas esas conversaciones se nos presentan: un estilo vertiginoso que se despliega en medio de una oralidad heteroglósica que mezcla las jergas populares, las palabras en otros idiomas, las terminologías médicas, los "slogans" publicitarios, letras de canciones, narraciones deportivas, etc. A ese tenor, léanse las siguientes muestras:

Y aquí estoy a un poco más de cuatro mil millas de la meseta central en donde Gerty levita en este momento, se está yendo a la cama Sonia Jones, los pintores nacionales de fama internacional, Angelito y Joselito, siguen soñando y roncando, se celebra otra gesta deportiva, que llega a todos ustedes por cortesía de la cabalgata deportiva Gillete que esta mañana como siempre, se dispone a traer a todos ustedes amigos fanáticos, los pormenores de nuestra cartelera deportiva en la que se destaca en letras de oro y números romanos, el partido entre el campeón mundial Deportivo Saprissa, Saprissa, Saprissa, y los polos de Alajuela que hasta hoy no nos ven ni el arranque porque, oigan ustedes: en la portería, el cholo Sanabria, defensa derecho Alex Sánchez, central catato Cordero, izquierdo Alexis Agüero...

Esperamos, como siempre que juegan estos gigantes, un cotejo reñido, parejo, de grandes acciones en donde una delantera incisiva como la del equipo morado, una defensa aguerrida 


\begin{abstract}
como la manuda, nos brindarán una sucesión de epifanías, revelaciones, momentos efímeros pero imborrables que jamás podremos olvidar, llega a mi corazón esa dulce emoción, porque aquí en Puntaremas todo es una ilusión que más tarde se irá...Y ahora, desde su centro social, El Patio, en la Perla del Pacífico, desde el lugar en que se divierten las buenas familias del puerto, cincuenta varas para abajo del muelle, el ñato Cubero y su magnífica orquesta les deleitará con la melodía del croner mexicano y compositor, Luis Alcaraz, cuya canción Viajera, dedicamos a la familia MacDowell Hurtado que nos honra con su presencia, para sus encantadoras hijas, Gerty y Luz, dos flores de la mejor sociedad porteña...ay, pero qué bien que bailan las hermanitas Macdowell, yo les doy clases de baile todos los viernes y los sábados, tienen una facilidad bárbara para moverse, qué muchachas, qué bien que lo menean... El club social El Patio en donde como siempre se da cita lo mejorcito de nuestra sociedad, se enorgullece ahora en presentar...un momento, por favor, nos acaba de llegar el resultado del partido de esta mañana entre el equipo alajuelense y el equipo Saprissa. Noticia calientita: Alajuela dos, Saprissa cero. Un momento señores, por favor, por favor, no quiebren las mesas...llamen a la policía... (Mora 1998: 40-1).
\end{abstract}

Lo anterior es importante en el sentido de que, con la modulación oral, las estrategias de la escritura se independizan del "establishment" y se intenta adecuar la literatura al oído y al habla cotidiana.

No obstante, la cultura popular está enmarcada en este relato por los medios electrónicos. Es precisamente el hecho de que todos los relatos de Mora se encuentran en su Toshiba, lo que le permite a Moro aprender a destruir toda consecutio temporum y enroscar las cadenas causales en una especie de espiral en la que se rompen los principios de la racionalidad común, haciendo desaparecer el principio de identidad y de no contradicción en favor de una espacialidad sin límites y de un tiempo que pierde toda absolutez en un universo textual completamente curvo. Pero los ejercicios de estilo de Polo comienzan en sus andanzas por los mundos ficcionales encerrados en la computadora:

\footnotetext{
Desde que descubrí que se volvía corporéo, que salía de vez en cuando a darse la vuelta, me he dado cuenta de que, primero: no es de vez en cuando. Es casi a diario. El tipo se pone unos jupetes de señor y padre mío. Esta mañana, por ejemplo, llegó por obra y milagro de Dios. A Dios gracias, había dejado la computadora encendida. Con todo y eso, hizo un escándalo del carajo. Se metió en el asilo. De ahí salió gritando como si estuviera viendo los azules. Se metió en La Peni, en un bar de negros en New Orleans. La quinta fue la vencida: terminó en su archivo, Memorias de un Psiquiatra. Por eso no empecé a trabajar temprano. No quería martirizarlo. Imagino que cada teclazo le debe sonar como un bombazo. Gajes del oficio (Mora 1998: 62).
}

Los lugares en que se interna Polo, al equivocarse de archivo, son solamente reconocibles para los lectores de sus otras obras. Quien las conoce sabe o puede imaginar lo que esas equivocaciones de Polo le pueden ocasionar. Cada archivo es un mundo aparte, otra dimensión y, sin embargo, quedan conectados con la intromisión de Polo quien, además, de vez en cuando saca a los personajes para que visiten otros archivos o los lleva a trasnochar por las calles de Madrid, como ya vimos que hizo con la Juana, o como cuando los invitó a la famosa fiesta que organizó en la casa 313 de la novela La Loca Prado.

Continuando con el tema de la oralidad y su contribución a este mundo curvo y sin fronteras de Mano a Mano, es importante considerar cómo su temporalidad fugaz se convierte en el principio discursivo que organiza la escritura. De ahí que se avenga bien a esa especie de contemporaneidad prolongada del relato, una contemporaneidad tan insistente 
que, inverosímilmente, en ese mundo curvo, conviven personajes literarios con los reales que algún lector es capaz de señalar con el dedo muy cerca de sí.

No obstante, la impureza linguística de lo oral al mezclar diferentes sociolectos (jergas, chistes verbales, registros publicitarios, jurídicos, médicos y notas aclaratorias), también produce los efectos contrarios: hermetismo, densidad extrema, dispersión del sentido, alteración semántica y efectos paródicos y polisémicos. Todo lo cual perturba la coherencia y la integración del sentido. Al respecto, obsérvese la cita que transcribimos a continuación:

\footnotetext{
Tu relato a veces pierde cohesión, Polo. Te vas por las ramas. Te estimulas demasiado. Yo tengo muchos años de hacerlo. A lo mejor eres muy sensible a la cafeína. A veces escribes como un esquizofrénico, tus ideas en ocasiones vuelan como pájaros en estampida...

...El Cogentin me ayuda, doctor. Pero ahora veo doble. Quíteme la medicina, doctor. Quíteme esta porquería o no vuelvo.

Reemplacemos el Largactil por Stelazine, Stelazine 5 miligramos tres veces al día. La misma cantidad de Cogentin...

Hace días que no me lee nada.

Cierto, doña Celina, ¿qué se hizo el libro?... Aquí...

Las flores sobre la tumba de Celina Garcilaso se marchitaron apenas el grupo de amigos que la acompañó al campo santo (sic) dejó el lugar (Mora 1998: 146).
}

Como dice Eco (1992), esta literatura es hija legítima de Hermes, dios que no conoce fronteras espaciales y que puede estar, bajo formas diferentes, en lugares distintos al mismo tiempo. Así, tanto esta novela de Mora como el conjunto de su obra son un verdadero proceso intertextual al servicio de un único proyecto literario, pues vuelven las unas sobre las otras para contarnos siempre lo mismo: la saga de un yo, el desarrollo de una conciencia. De un texto a otro, Mora no hace más que buscarse. Toda su obra, pero muy especialmente Mano a mano, es un espacio daimónico de encuentro consigo mismo. Sin embargo, el yo no es algo que esté allí, en ese espacio interior, y que uno pueda descubrir, sino algo que hay que crear, construir, precisamente ubicándose fuera de la propia subjetividad y ensayando borrones del yo, formas distintas cada vez. La escritura se convierte así en un mecanismo mediante el cual el yo se desposesiona de sí mismo para convertirse constantemente, como dice Foucault, en otro distinto de quien es, abriéndose a las multiplicidades que lo atraviesan en el confesionario de su conciencia dialógica. Polo Moro es la exterioridad que le permite a Mora borrar ese fantasma que es la identidad del sujeto y entre ambos hacen de ese yo que dialoga consigo mismo en sus escritos tan sólo el chispazo que es posible avizorar en el breve instante de la enunciación. Cuando Mora habla de Polo, afirma lo siguiente:

\footnotetext{
En fin, que si sigo pensando en su vida, voy a tener que dejar estas líneas inconclusas para salir y tomarme un trago... lo usé de trapito de lágrimas y cuando él quiso respirar, asomarse al mundo, me llené de un odio mortal. ¿Por qué, Gerty, por qué? Creo que te lo insinué ayer: porque me parezco a él, porque me veo en él... especialmente en lo feo, lo mezquino, lo mentiroso (Mora 1998: 34-5).
}

Como decíamos anteriormente, para rematar en el tema, el relato de Polo es también un relato de identidad en el que los personajes se resisten a aceptar la identidad que el escritor les otorga. Por eso Jimmy, el supuesto padre de Tato Garcilaso, se rebela contra el "plot" planeado por Polo: 


\begin{abstract}
¿Y qué hizo usted cuando se dio cuenta de la tragedia?
Lo que hubiera hecho cualquiera: traté de razonar con Jimmy sin resultado. El Jimmy está dispuesto a matarlo las veces que sean necesarias, aunque me oponga yo, aunque se oponga el cielo, así dijo. Me tiene entre la espada y la pared. Sabe de la lucha que yo he sostenido con usted en aras de mi libertad, de mi autonomía. ¿Sabe lo que me dijo? Creí que el aceite de la gansa era bueno también para el ganso. O algo por el estilo. No recuerdo haber oído ese decir. Empero, creo que es obvio su significado...

Yo...

Yo. Siempre yo, yoísta de mierda.

No se enoje, Polo. No es este el momento más oportuno para perder la cordura. Tiene usted entre manos una crisis, una crisis que tiene remedio.

¿Remedio? (Mora 1998: 92-3).
\end{abstract}

Moro aparece en los textos de Mora, después de que éste último ha venido dando fragmentariamente retazos pseudoautobiográficos en los textos anteriores, como en el cuentario La distancia del último adiós. Polo nace en Bordeaux, la ciudad donde Mora escribe el último renglón de Memorias de un Psiquiatra, obra de síntesis que trata de poner en orden cronológico (aunque este orden termina por ser axiológico), muchos de los eventos que habían aparecido dispersos en sus libros anteriores. Es entonces que comienza a adquirir forma el primer borrón de su autoimagen, pero en este borrón el papel de su personaje y doble es crucial, pues es gracias a la ayuda de Moro que Mora comprende que en él se reúnen, al igual que en Hermes, todos los contrarios. Por eso, su retrato, del cual transcribimos tan sólo un segmento, no puede tener otra forma que la del oxímoron:

Yo soy lo bueno y todo lo malo de que es capaz un hombre...

Pero sobre todo, soy mis memorias, mis palabras, mis padres, mi tierra...

Soy música.

Soy una mujer con pinga

Soy esto, todo y nada. ${ }^{2}$

La oralidad y los géneros vulgares, por cotidianos, nos conducen al spoudogéloion pero... ¿cómo hacer coincidir, entonces, los géneros del spoudogéloion, caracterizados, como dice Bajtín, por una ausencia de la base compositivo-argumental que suele atribuírsele al género novelístico tal y como hoy lo conocemos, con esa literatura de vanguardia a la que Eco (1992) llama literatura hermética? Me parece que, en ese sentido, esta novela de Mora se presta perfectamente para explicar el entronque.

Recordemos en primer lugar que los géneros del spoudogéloion reúnen variados especímenes, los cuales se hacen en su mayoría presentes en el estilo de Mano a mano, pues este relato es heteroglósico (mezcla de variadas voces sociales y sus diastrasías); menipeo, por carnavalizado; dialógico, por estructura y composición; escatológico, por las crueles escenas del relato enmarcado que autor y personaje van construyendo (la terrible historia de Tato Garcilaso y su abuela "desalmada", la negra Tomasa).

Según Bajtín, mejor que en la denominada "novela griega", el espíritu de la novela moderna y su embrión se halla en los géneros del spoudogéloion. La razón es la siguiente: los géneros de lo serio-cómico logran una transformación radical en el proceso de formación de la novela moderna al romper la absolutez del tiempo épico y la distancia jerárquica. Gracias a ellos, por primera vez en la novela se introduce el punto de vista de la contemporaneidad y se 
logra el desendiosamiento del autor, porque lo cómico es precisamente la zona del contacto familiar y cotidiano. De ahí que en esta novela de Mora priven la oralidad y las jergas ordinarias con su contemporaneidad; de ahí también que el autor sea constantemente cuestionado y contradicho por el personaje y se convierta en ese oxímoron que el retrato de Mora nos ha revelado. Pero lo más importante, quizá, es el trasfondo filosófico que todo esto arrastra: en el devenir de la realidad que, según Bajtín, sólo la novela sabe captar de modo profundo, la imagen novelística del hombre revela la identidad como un proceso.

Según Bajtín, en el spoudogéloion está el germen de los temas internos más importantes de la novela: la imagen del hombre y la novelización de la novela misma, todo lo cual es comprobable en Mano a mano. Veamos por qué.

Al introducirse, gracias a los géneros serio-cómicos, la contemporaneidad y lo variable y perecedero de la realidad cotidiana, esa zona de contacto con el presente inconcluso trae como consecuencia la inserción de la idea de futuro, del devenir y, por lo tanto, el héroe, en este caso, el autor representado, no puede agotarse en la última palabra. Por eso Mano a mano insiste en denunciar por una parte la no coincidencia del autor representado consigo mismo, y por otra, la no coincidencia de los personajes que Polo Moro crea en un nivel con las réplicas que de estos aparecen en otro nivel:

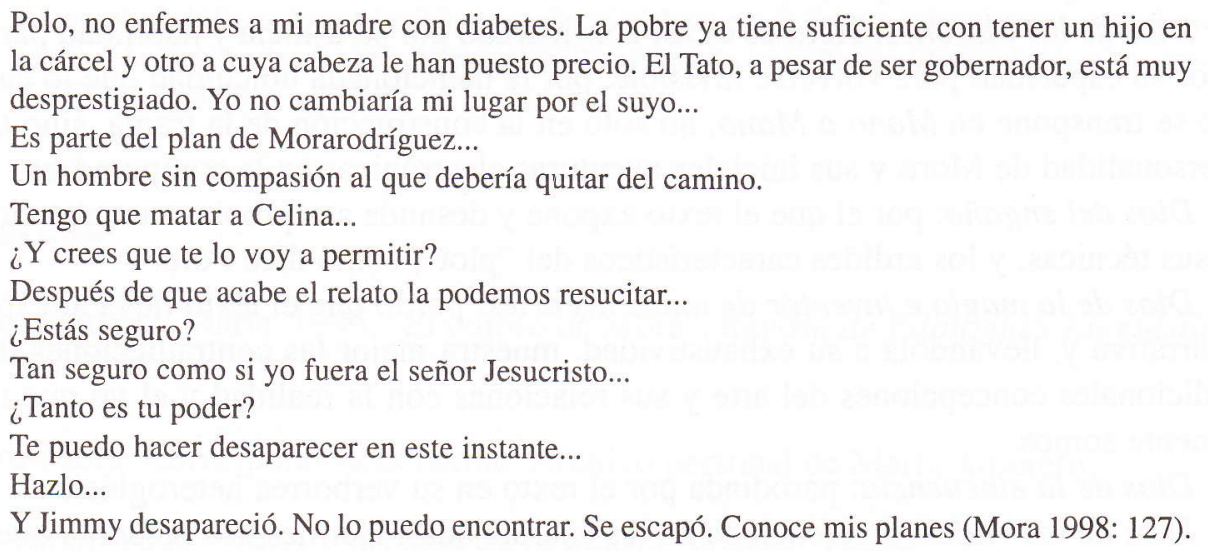

Todo lo anterior conduce a lo que el mismo Bajtín afirma en cuanto a que la propia realidad novelística es una de las realidades posibles, pero lleva dentro de sí otras realidades posibles:

\footnotetext{
¿Remedio?

Mate al negro.

Cómo se le ocurre. Matarlo cuando todavía no ha revelado su lado de la historia. Ni siquiera sabemos si es de verdad el padre. Suponga que rehúsa a aceptar la paternidad de Tato Garcilaso. El hombre es un rebelde. Tengo grandes planes para él. Sería una imbecilidad acabar con él en este momento. Destrozaría mi topos, el triángulo, un triángulo que como usted ve, me da gran movilidad, me permite reflejar la historia en varios espejos. No he llegado a la mitad del plot, y usted quiere que me apresure asesinando a los personajes principales. Morarodríguez no lo entiendo..

¿Qué piensa hacer?

Seguirle el juego, dejar que sus instintos primarios se desborden... (Mora 1998: 93).
} 
Lo último explicaría lo que actualmente se conoce como "mise en abyme", y que resulta ser en Mano a mano uno de los efectos más recurrentes y la causa de una constante problematización no sólo del proceso productivo, sino sobre todo del modo de consumo del texto y su complicadísima lectura.

Por eso, y para ir concluyendo, podemos afirmar que la figura mítica de Hermes y su imagen irreconciliable y divergente presagia eso que hoy se denomina "mise en abyme", para convertirse luego en las teorías de Eco, en la propia emblemática de las vanguardias estéticas y críticas más atrevidas de este fin de siglo, entre las cuales, la obra de Mora se erige como una muestra muy representativa.

En resumen Hermes y la literatura hermética con su hermenéutica característica, se pueden asociar en Mano a Mano de la siguiente manera:

Dios mediador: la función mediadora del dios entre lo trascendental y lo divino se relee en Mano a Mano entre lo real y lo ficticio.

Dios ubicuo: lo cual remite al carácter curvo de la realidad narrativa de Mano a Mano y su pervertida intelección. Hay que recordar que, gracias a Hermes, se incluye en el mundo clásico una forma singular de la existencia en la que tiene cabida lo bueno y lo malo, lo elevado y lo ordinario, como sucede en Mano a Mano y sus fantasmagóricas realidades e identidades.

Dios de los ladrones: Hermes es así considerado por su astucia y habilidad para el engaño, por su capacidad para volverse invisible, por la mencionada ubicuidad que lo caracteriza. Esto se transpone en Mano a Mano, no sólo en la construcción de la trama, sino también en la personalidad de Moro y sus iniciales aventuras electrónicas en la computadora.

Dios del engaño: por el que el texto expone y desnuda sus propias maquinaciones internas, sus técnicas, y los ardides característicos del "plot", como dice Polo.

Dios de la magia e inventor de todas las artes: por lo que el texto lleva al extremo la tecné narrativa y, llevándola a su exhaustividad, muestra mejor las contradicciones de nuestras tradicionales concepciones del arte y sus relaciones con la realidad y el yo que tan sólo virtualmente somos.

Dios de la elocuencia: parodiada por el texto en su verborrea heteroglósica.

Dios de los viajes: reverenciado en las encrucijadas, Hermes nos recuerda que la mayoría de los textos de Mora, no sólo éste, son textos viajeros.

Dios conductor: las alas talares de Hermes le permiten desplazamientos veloces como los que se dan en Mano a Mano y que producen el vértigo del que ya hicimos mención.

Toda esa serie de recurrencias y analogías se integran en el nivel superior de la resonancia irónica y de la risa, propia del spoudogéloion, detrás de la cual se destaca la figura de Dionisos, dios de la emancipación y de la supresión de las prohibiciones y tabúes, y en cuyos valores se inspiran las religiones mistéricas que florecieron al principio del mundo grecorromano y que van a resurgir de alguna manera en la filosofía cínica de la época imperial.

El culto dionisíaco testimonia el violento esfuerzo de la humanidad por romper la barrera que la separa de lo divino. Para liberar el alma de los límites terrenos, en este culto se intenta una exotopía a través del éxtasis hedónico, los desbordamientos sensuales -tan comunes en toda la obra de Mora- y la liberación de lo irracional. No en vano, Nietzsche recupera la tradición dionisíaca y Foucault rinde culto a Diógenes, el cínico, en quien la búsqueda del hombre 
y el "conócete a ti mismo" ( $\Gamma \vee \varpi \vartheta \imath ~ \sigma \varepsilon \alpha u \tau \delta ́ v)$ no pueden entenderse sin la asunción de una auténtica libertad, libertad en la que la parrhesia (libertad de palabra), más que la anaideia (libertad de acción), ocupa un lugar relevante.

Sin embargo, las relaciones pueden extenderse mucho más allá de donde hemos quedado. Por lo pronto contentémonos con señalar que esas homologías entre Hermes, Dionisos y Diógenes podrían explicar mejor cada uno de los elementos del spoudogéloion y el porqué Bajtín excava en las formas de la novela moderna sus fuertes raigambres con el mundo clásico.

\section{Notas}

1. Ver bibliografía que se adjunta y referirse a la inaudita ficha bibliográfica que allí se transcribe en la que, obedeciendo la portada de la publicación de Ediciones Universal, no nos ha quedado más remedio que incluir la versión de La Película cuya autoría Polo le birló a Mora en 1995. Las extravagancias ficcionales de Mora son efectivamente performativas pues varían significativamente incluso los actos y declaraciones de propiedad inscritos en la relación jurídica de los bienes intelectuales adscritos a la práctica académica.

2. El poema del que es tomado este fragmento se titula "Ese soy yo" y fue enviado por el autor a María Amoretti también en forma faxilar, pero ella lo incluyó en un artículo titulado "Dos momentos dos autores en la historia de una literatura nacional", publicado en la Revista de Filología y Lingüística. Vol. XXVI, nº. 2, 2000.

\section{Bibliografía}

Amoretti Hurtado, María. 1995. "El odioso de Mora". Revista de Filología y Lingüística. XXI (2): 7-16.

Amoretti-Mora. Correspondencia faxilar. Archivo personal de María Amoretti.

Bajtín, Mijail. 1989. Teoría y estética de la novela. Madrid: Taurus.

Chevalier, Jean y Gheerbrant. 1995. Diccionario de los símbolos. Barcelona: Herder.

Eco, Umberto. 1992. Los límites de la interpretación. Barcelona: Lumen.

Matarrita Matarrita, Estébana. 1998. Humor, filosofía y Literatura en un texto costarricense. Ponencia presentada en el III Congreso Internacional sobre el humor lusohispano. Sudbury, Canadá.

Mora, V. A. 1979. Cachaza. San José: Editorial de la Universidad de Costa Rica. 1998. Mano a mano. San José: Editorial Icode. 
Memorias de un Psiquiatra. El final del comienzo o viceversa. Texto inédito. Manuscrito proporcionado por el autor para efectos de esta investigación.

1995. La distancia del último adiós. San José: Editorial Universidad de Costa Rica. 1991. La Película. San José: Editorial de la Universidad de Costa Rica.

Morales y Marín, José Luis. 1984. Diccionario de iconología y simbología. Madrid: Taurus. Moro, Polo. 1995. La Película. Florida: Ediciones Universal.

Otto, Walter. 1975. Los dioses de Grecia. Argentina: Editorial Universitaria de Buenos Aires.

Reale, Giovanni y Dario Antiseri. 1995. Historia del pensamiento filosófico y científico I. Barcelona: Herder.

Todorov, Tzvetan. 1981. Mikhail Bakhtine. Le principe dialogique. Suivi de Écrits du Cercle de Bakhtine. París: Seuil. 